UDK 624.02

O. SLIPYCH, cand. of Tech. Sci., doc., LLC "Industrial Construction Group",

K. ROMANENKO, cand. of Tech. Sci., doc., D. KRAVTSOVA, cand. of Phys. and Math. Sci.,

O. BONDAR, cand. of Tech. Sci., doc., Kryvyi Rih National University

\title{
INSTALLATION OF A STATIONARY HYDRAULIC HAMMER AT A HEIGHT
}

Purpose. The article presents a non-standard project for the installation of heavy dynamic equipment at a height - stationary hydraulic hammer.

Research method. It has been illuminated the result of visual and instrumental flaw detection performed by special tools of non-destructive testing and laboratory tests and measurements of constructive elements of a building in which it is necessary to install the hammer. The calculations are made in the software complex "LIRA CAD 2013", which implements the finite element method in displacements.

Scientific novelty. It has been demonstrated the loads calculation on the foundation of the hammer and the plan for its installation at mark of 13,640 meters. It has been analyzed current methods and recent studies of beam reinforcement.

Practical value. After analyzing current methods and recent studies of beam reinforcement, the authors conclude that reinforcement of beams with metal clamps is the most appropriate in this case. First of all, metal can withstand dynamic loads; it does not crumble under tensile forces. Secondly, economic indicators have played a significant role in the selection of the material: the reinforcement project was ordered in the region of iron ore and steel production, so the cost of metal is much lower than the cost of carbon-fiber tapes.

Results. Necessity has been substantiated: (I) strengthening reinforced concrete beams MB52-1 at the mark $+13,640$ in the axes 4-6 and E-F; (II) installation of steel beams under the foundation of the hammer; (III) installation of shields of the fixed formwork of the hammer foundation. Some recommendations were given.

Key words: install at the height, strengthening reinforced concrete beams, dynamic load, stationary hydraulic hammer.

doi: 10.31721/2306-5451-2021-1-52-64-70

Problem and its connection with scientific and practical tasks. At modern mining enterprises there is a need for additional crushing of large debris of a rock near a crusher when they get stuck in a hopper. For this, stationary hydraulic hammers are used. Its installation at the plant requires careful calculation of the supporting structure due to the large weight of the hammer and its foundation and the presence of dynamic loads. Especially non-standard task is to install it at the height at the operating enterprise.

The purpose of the work is the project of installing a stationary hydraulic hammer ALTA GR-158 at a mark of $+13,640$ in the building of the large crushing corps of the mining processing plant in the Poltava region of Ukraine. The free space in the building is the unused mounting cavity between the crushers' hoppers. This building is not designed for such equipment. The tasks are: checking existing structures, calculating loads and designing the installation of heavy dynamic equipment at a height that meets the requirements [1-7].

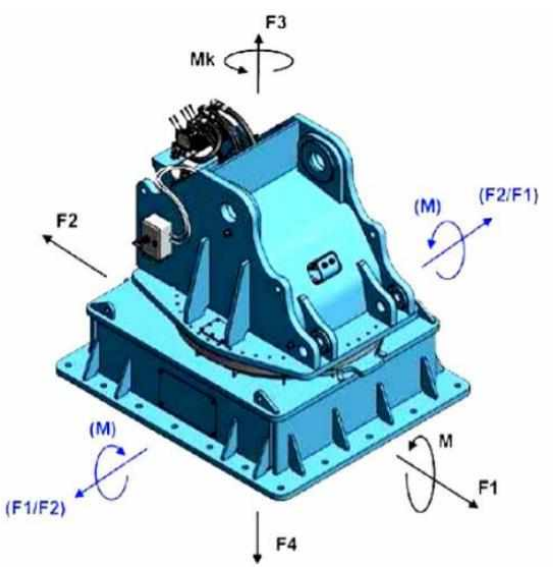

Fig. 1. Scheme of load on the foundation of the hammer GR-158

Methodology and problem statement. The level of the clean surface of the first floor of the building is taken as a mark of 0.000 . The building of large crushing corps is a building with a developed underground part with a mark $-17,800$ to $+13,640$. The load-bearing elements of the building are reinforced concrete well with monolithic reinforced concrete ceilings, crusher foundations and hoppers. From the mark $+13,640$ to $+38,250$ the building is a steel frame enclosed with profiled sheets.

We carried out the construction inspection by methods of computational and analytical diagnostics, which use data from visual and instrumental flaw detection performed by special tools of non-destructive testing and laboratory tests. They allowed determining the physical and mechanical properties of construction materials with a sufficient precision and without destruction. List of works performed during inspection: detection and fixation of visible defects and damage; determination of parameters of the environment of operation; creating a description, sketches and photographs of defective areas; drawing up of schemes and information of defects and

(C) Slipych O., Romanenko K., Kravtsova D., Bondar O., 2021 
damages; detection of characteristic deformations of buildings (deflections, rolls, bends, distortions, faults, etc.) and emergency areas. In addition, verticality and parallelism of load-bearing elements were checked. In reinforced concrete structures we identified signs of corrosion of reinforcement and embedded parts, the condition of the protective layer, the presence and measurement of cracks.

The main elements that will be considered additional loads are monolithic reinforced concrete beams MB52-1 intersection of $500 \times 1500 \mathrm{~mm}$ and monolithic reinforced concrete bunker walls MBSS1 in the thickness of $1000 \mathrm{~mm}$. At the time of construction inspection, the general state of ceiling at +13.640 in the axes 4-6 and D-G of the building is stable. The state of construction and assemblies, their connections are without changing the geometric characteristics of the constructive scheme. According to the requirements [8], the inspected building structures of the ceiling on the mark $+13,640$ in axes 4-6 and D-G can be classified as satisfactory. The constructions are in a state of effective condition. Damage and defects affecting the load-bearing capacity are absent.

In most cases, hydraulic hammers are equipment for hydraulic excavators. The principle of operation is the same as a hand-held jackhammer, but the impact energy is more than a thousand times. Most often they are used for loosening of frozen soil, destruction of pavements, crushing of oversized rocks, concrete structures, etc. In crushing factories, the hydraulic hammers are installed stationary above the level of the crushers, but, firstly, these are isolated cases, and secondly, the installation requires individual design.

Table 1

The load on the ceiling at the mark $+13,640$

\begin{tabular}{|c|c|c|c|c|}
\hline Load type & Normative load & $\begin{array}{c}\text { Load reliability } \\
\text { coefficient } \gamma_{\mathrm{f}}\end{array}$ & $\begin{array}{c}\text { Dynamic } \\
\text { coefficient } \varepsilon\end{array}$ & $\begin{array}{c}\text { Calculated } \\
\text { load }\end{array}$ \\
\hline \multicolumn{5}{|c|}{ Situation 1 (active rolling stock and inactive hammer) } \\
\hline Temporary on the railway, kN/r.m. & 140 & 1,3 & 1,1 & 200 \\
\hline $\begin{array}{l}\text { Temporary on removable shields and free areas } \\
\text { of concrete floor, } \mathrm{kN} / \mathrm{m}^{2}\end{array}$ & 4 & 1,2 & & 4,8 \\
\hline Static from the hammer, $\mathrm{kN}$ & 280 & 1,2 & & 340 \\
\hline \multicolumn{5}{|c|}{ Situation 2 (inactive rolling stock and active hammer) } \\
\hline $\begin{array}{l}\text { Temporary on removable shields and reinforced } \\
\text { concrete ceilings, } \mathrm{kN} / \mathrm{m}^{2}\end{array}$ & 4 & 1,2 & & 4,8 \\
\hline Static from the hammer, $\mathrm{kN}$ & 264 & 1,2 & & 317 \\
\hline $\begin{array}{l}\text { Temporary from the hammer (F1-F4, M, Mk), } \\
\mathrm{kN}, \mathrm{kN} \cdot \mathrm{m}\end{array}$ & Fig. 1, table 2 & & 2,5 & \\
\hline
\end{tabular}

Table 2

Normative load on the foundation of the hammer GR-158 (F1-Mk - dynamic load, G - static load)

\begin{tabular}{|c|c|c|c|c|c|c|c|}
\hline GR 158 (fig. 1) & $\begin{array}{l}\text { F1 } \\
\text { kN }\end{array}$ & $\begin{array}{l}\mathrm{F} 2 \\
\mathrm{kN}\end{array}$ & $\begin{array}{l}\text { F3 } \\
\text { kN }\end{array}$ & $\begin{array}{l}\mathrm{F} 4 \\
\mathrm{kN}\end{array}$ & $\begin{array}{c}\mathrm{M} \\
\mathrm{kN} \cdot \mathrm{m}\end{array}$ & $\begin{array}{c}\mathrm{Mk} \\
\mathrm{kN} \cdot \mathrm{m}\end{array}$ & $\begin{array}{c}\mathrm{G} \\
\mathrm{kN}\end{array}$ \\
\hline Max F1 & 345 & & 149 & & -424 & 158 & 250 \\
\hline Max F2 & & 1189 & & 92 & 1307 & 158 & 250 \\
\hline Max F3 & 120 & & 456 & & -438 & 158 & 250 \\
\hline Max F4 & & 261 & & 1130 & 1260 & 158 & 250 \\
\hline Max M & & 1017 & & & 1625 & 158 & 250 \\
\hline Max -M & 283 & & & & -548 & 158 & 250 \\
\hline
\end{tabular}

A base hammer plate with bolts $(2145 \mathrm{~kg})$ is supplied by the manufacturer of hammer ALTA GR$158(28000 \mathrm{~kg})$.

We took into account the results of diagnostics, hammer characteristics and calculated the MB521 beam at the $+13,640$ mark on the 4-6 and F-E axes, which will handle additional loads. The purpose of the calculations was to determine the stress-strain state of beams from constant and temporary loads, the nature of the distribution of internal forces, the zones of concentration of the greatest stresses. The calculations are made in the software complex "LIRA CAD 2013", which implements the finite element method in displacements. As results table 1 and table 2 show the load on the ceiling on the mark $+13,640$ without specifying the weight of the structures. It shows that monolithic reinforced concrete beams MB52-1 will not withstand the additional load from the hammer at the mark $+13,640$ in the axes 4-6 and E-F because the load-bearing capacity of the beams in transverse force is exhausted. In view of all this, to install the stationary hydraulic hammer GR-158 at +13.640 , reinforced concrete beams MB52-1 must be strengthened. In addition, installation of shields of the fixed formwork of the hammer foundation is need. 
Analysis of research and publications. Today carbon fiber reinforced polymer (CFRP) system is very popular method of reinforcement of beams. Many studies were investigated, which was offered different methods of anchoring the CFRP-reinforcement. The use of steel clamps was found to be the most effective [9-11]. A long-term experiment of work [12] confirms this.

The post-tensioned NSM (near-surface mounted) strengthening system shows good result of effective for improving the crack resistance of concrete structures [13].

However, in previous works, stationary loads were applied to the experimental beams. Dynamic loads are applied in our task and paper [14]. Authors [14] were described that the building was subjected to unidirectional and three-dimensional incremental seismic excitations and dual CFRP/PTMS (Post-Tensioned Metal Straps) retrofitting of columns and joints were effective at restoring the lateral stiffness of the building by $75 \%$.

Composite bonding steel plate (CBSP) is steel structure applicable to the beam bearing high load. According to the methodology of paper [15], the strengthened beam consists of two layers of epoxy bonding pre-stressed steel plates and the beam sandwiched in between. The bonding enclosed and prestressed U-shaped steel jackets are applied at the beam sides. As a result the applied plates and jackets jointly behave together with the beam under the action of epoxy bonding and the mechanical anchorage of the steel jackets [15].

Main statement and results. After analyzing current methods and recent studies of beam reinforcement, the authors conclude that reinforcement of beams with metal clamps is the most appropriate in this case. First of all, metal can withstand dynamic loads; it does not crumble under tensile forces. Secondly, economic indicators have played a significant role in the selection of the material: the reinforcement project was ordered in the region of iron ore and steel production, so the cost of metal is much lower than the cost of carbon-fiber tapes.

Fig. 2 shows the scheme for strengthening the design for the installation of the hammer, an oil station and an oil tank between crushers' hoppers. It is also necessary to install additional steel beams that support the foundation of the hammer and panels of fixed formwork - struts (fig. 3).

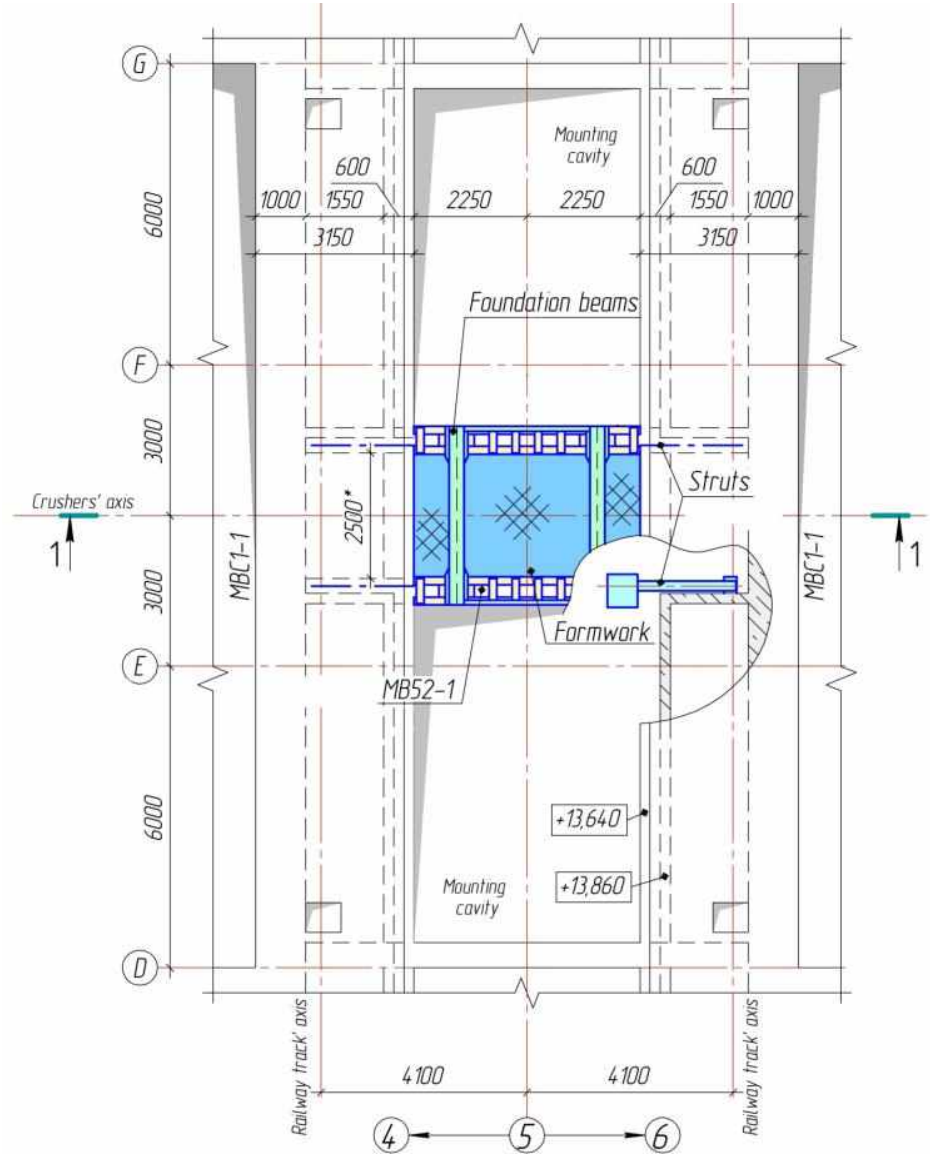

Fig. 2. The scheme of placement of strengthening elements, beams and shields of the formwork of the foundation of the hammer GR-158 at the mark $+13,640$ 
Fig. 3. Cross section 1-1 of fig. 2. The scheme of placement of strengthening elements, beams and shields of the formwork of the foundation of the hammer GR-158 at the mark $+13,640$

Table 3

Rolled metal products

\begin{tabular}{lcc}
\hline \multicolumn{1}{c}{ Metal products } & $\begin{array}{c}\text { Designations } \\
\text { in the drawing }\end{array}$ & $\begin{array}{c}\text { Total } \\
\text { weight, ton }\end{array}$ \\
\hline Hot-rolled steel strip metal & $-150 \times 14$ & 1.22 \\
Hot-rolled steel sheet metal & $-20 \times 240 \times 250$ & 2.01 \\
Hot-rolled steel corner metal & $\llcorner 160 \times 12$ & 1.3 \\
\hline
\end{tabular}

Fig. 4 shows scheme of installation of the clamps on the beams MB52-1. Different types of rolled metal products are used here (table 3). All structural elements are steel C245, which is analog E235-B (Fe360-B).

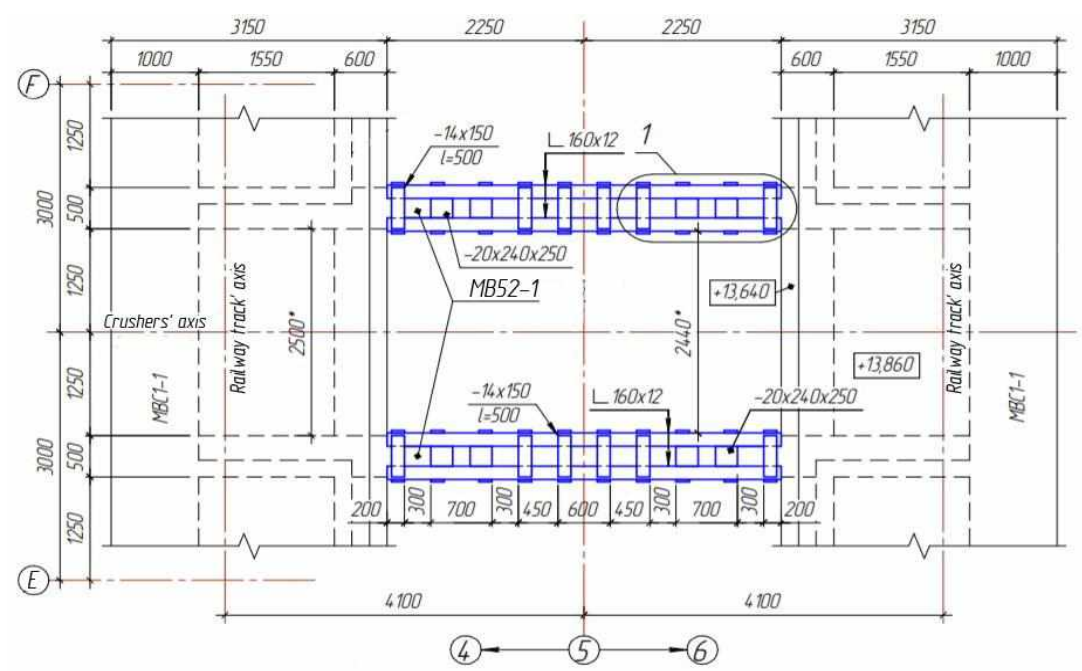

(1)
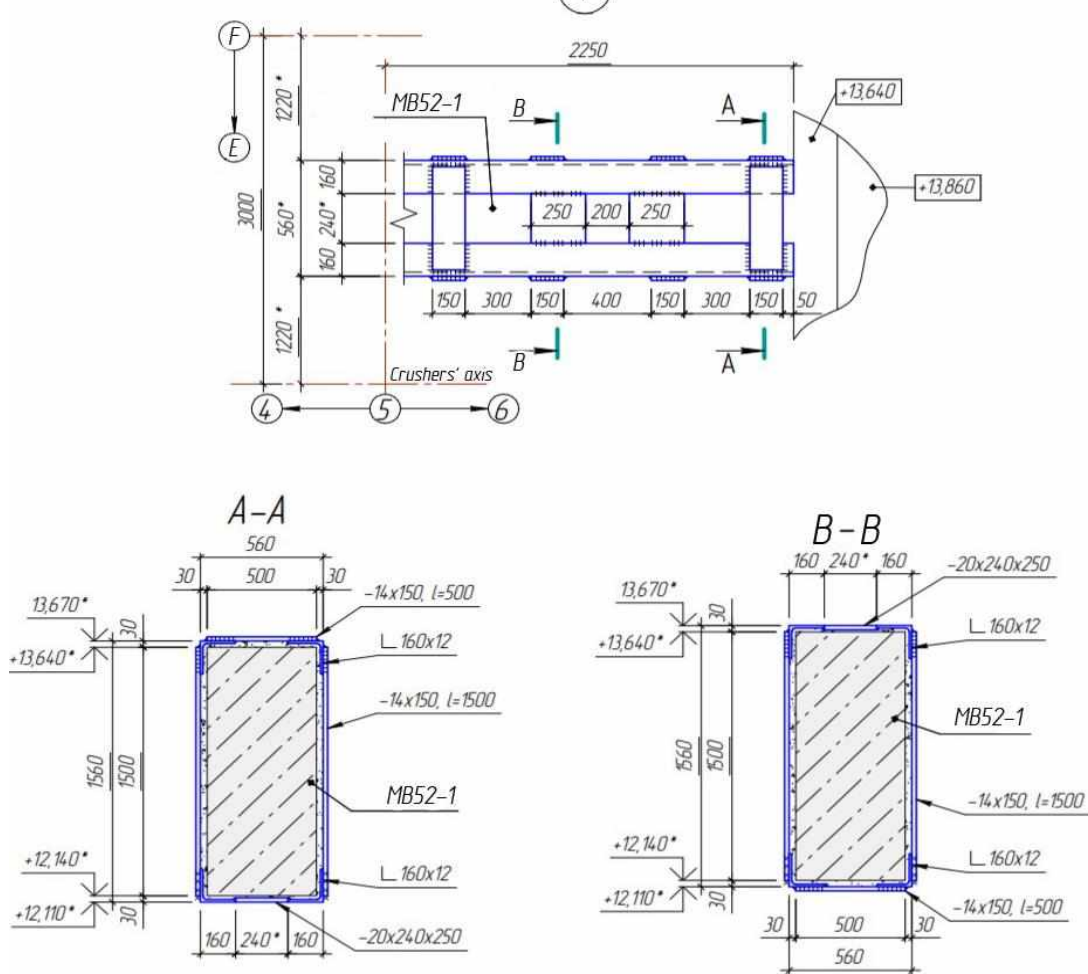

Fig. 4. Scheme of installation of the clamps on the MB52-1 beams 
The proposed strengthening elements will withstand own weight of the hammer foundation and its dynamic load or own weight of the hammer foundation and load from the railway rolling stock. But the strengthening elements will not withstand the dynamic loads of the hammer and movement the railway rolling stock at the same time. Therefore, the entrance of railway transport to neighboring hammer railways is prohibited during the operation of the hammer.

Figs. 5-7 show the plan for the installation of the hammer with an indication of its working radius at the marks $+6,450$ and $+13,640$. In accordance with the above plan, crushers' hoppers are located in the working area of the hammer.

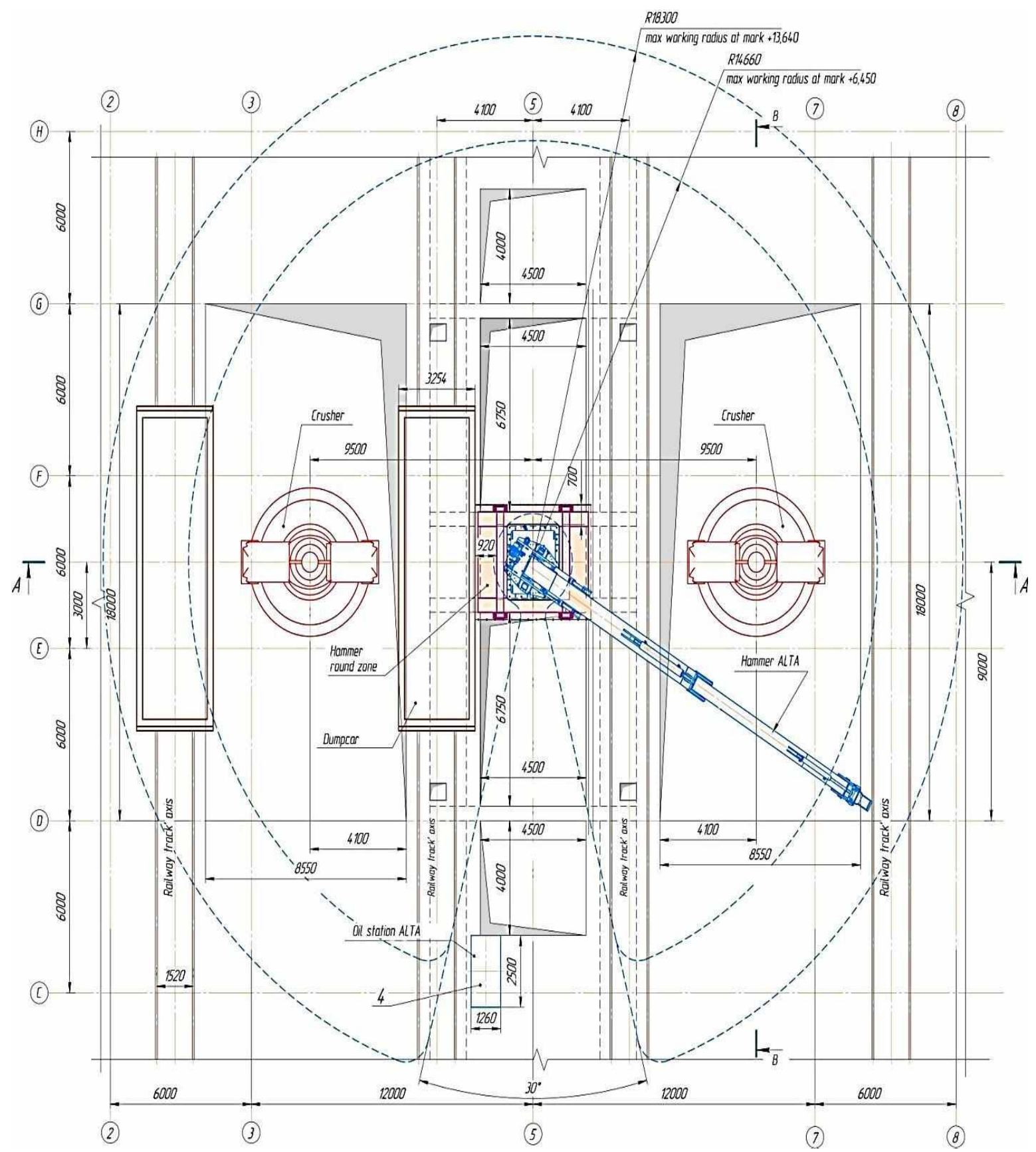

Fig. 5. The plan for the installation of the hammer GR-158 at the mark $+13,640$ 


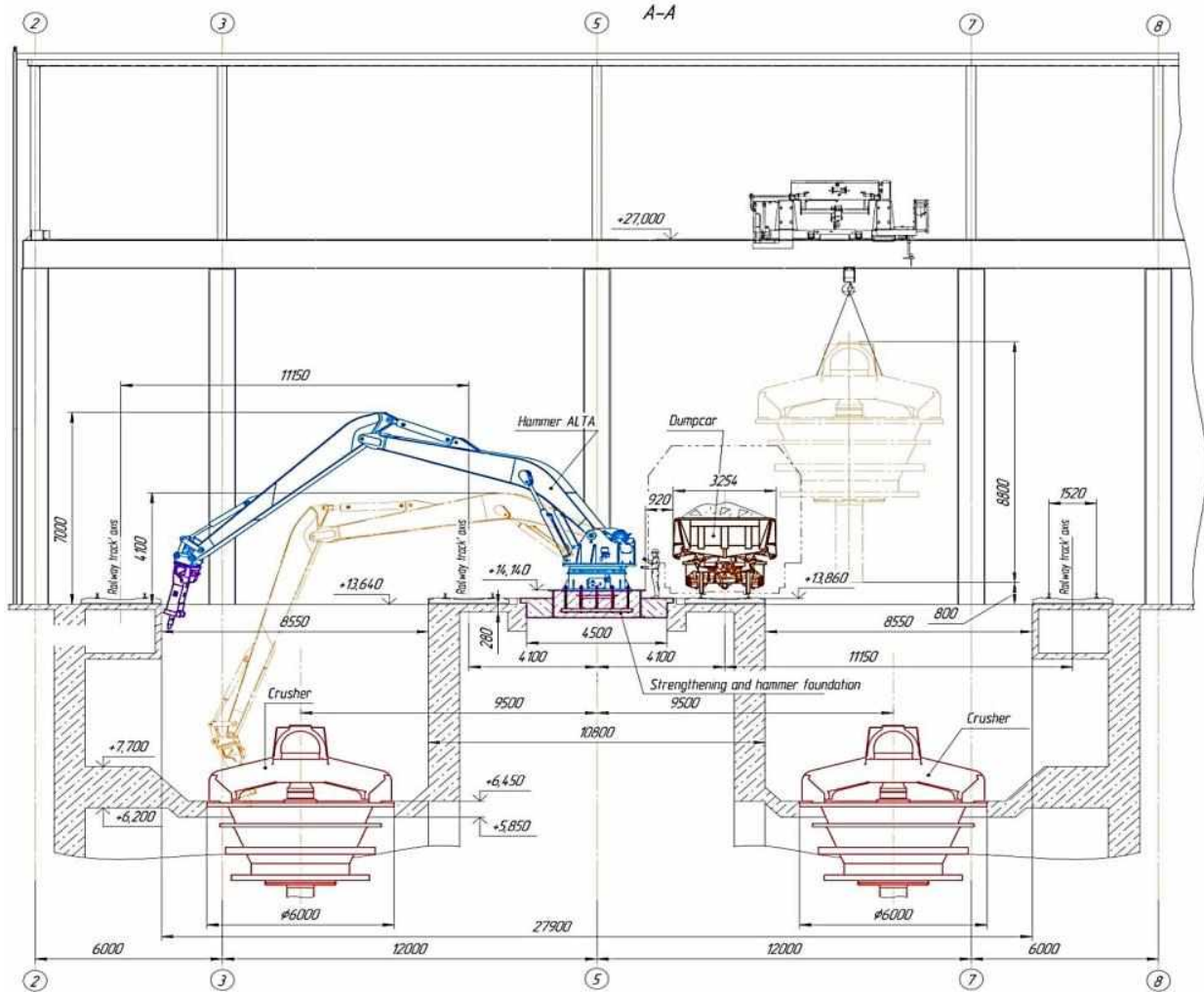

Fig. 6. The plan for the installation of the hammer GR-158 at the mark $+13,640$. Cross section A-A of fig. 5

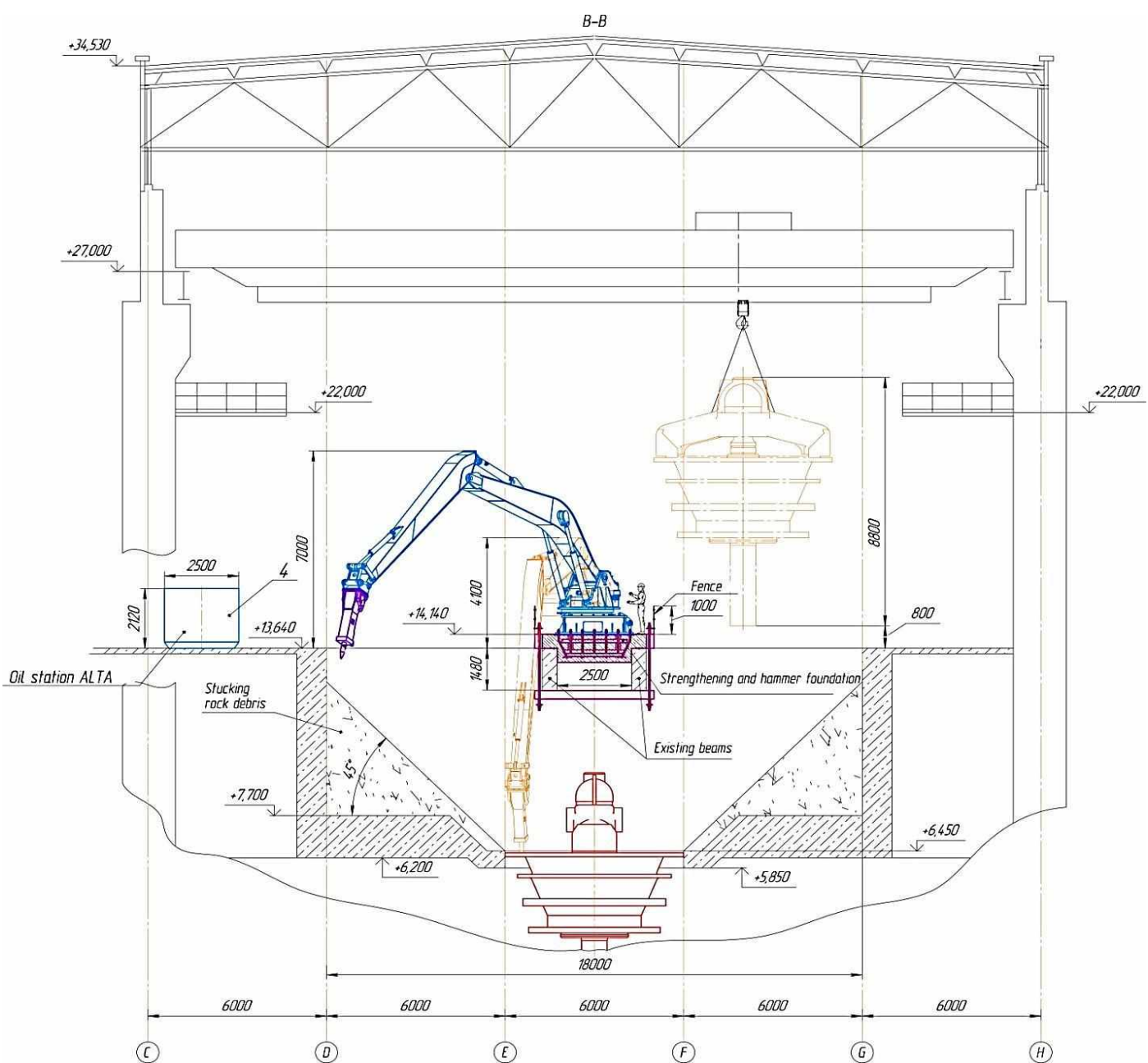

Fig. 7. The plan for the installation of the hammer GR-158 at the mark $+13,640$. Cross section B-B of fig. 5 
Conclusions and future work. It was decided to install stationary hydraulic hammer ALTA GR158 between the crushers' hoppers in the mounting cavity, which is not used during repair work, at the mark of $+13,640$ in the building of the large crushing corps of the mining processing plant in the Poltava region of Ukraine.

Necessity has been substantiated: (I) strengthening reinforced concrete beams MB52-1 at the mark $+13,640$ in the axes 4- 6 and E-F; (II) installation of steel beams under the foundation of the hammer; (III) installation of shields of the fixed formwork of the hammer foundation.

The installation project, which ensures the stability of steel structures at all stages of work, must be developed in advance. After installation the entrance of railway transport to neighboring hammer railways is prohibited during the operation of the hammer.

\section{References}

1. Turkstra C.J. Theory of Structural Design Decisions, SM Studies Series No. 2. Ontario, Canada: Solid Mechanics Division, University of Waterloo. 1970.

2. Eurocode - Basis of structural design : EN 1990:2002+A1. - Brussels : Management Centre, 2002. - 116 c. - (European Standard).

3. Eurocode 2: Design of concrete structures - Part 1-1: EN 1992-1-1:2004.- Brussels: Management Centre, 2008. - 225 c. - (European Standard).

4. EN 1991-1-3. Eurocode 1 - Actions on structures. Part 3: Actions induced by cranes and machinery - Brussels: CEN, 2003. $-43 \mathrm{P}$

5. Eurocode 3: Design of steel structures - Part 4-1: Silos : EN 1993-4-1. - Brussels : Management Centre, 2007. - 114 c. - (European Standard).

6. Barashikov A.Y., Malyshev O.M. Estimation of technical condition of building structures, buildings and structures. - K.: NMC Derznaglyadodohoronpraci Ukrainy, 1998. - 23 p.

7. DBN V.3.1-1-2002. Repair and strengthening of bearing and enclosing building constructions and bases of industrial buildings and constructions.. State Committee on Construction and Architecture of Ukraine. Kiev. 2003 - 82 pp. - (State building codes of Ukraine).

8. Gulvanessian H. and Holicky M. Eurocodes: Using Reliability Analysis to Combine Action Effects. Proceedings of the Institution of Civil Engineers Structures \& Buildings. August 2005, vol. 158, no. SB4, pp. 243 - 252.

9. Skuturna, T., \& Valivonis, J. (2016). Experimental study on the effect of anchorage systems on RC beams strengthened using FRP. Composites Part B: Engineering, 91, 283-290. https://doi.org/10.1016/j.compositesb.2016.02.001

10. Demir, A., Ercan, E., \& Demir, D. D. (2018). Strengthening of reinforced concrete beams using external steel members. Steel and Composite Structures, 27(4), 453-464. ) DOI: https://doi.org/10.12989/scs.2018.27.4.453

11. Helal, Y., Garcia, R., Pilakoutas, K., Guadagnini, M., \& Hajirasouliha, I. (2016). Strengthening of short splices in RC beams using post-tensioned metal straps. Materials and Structures, 49(1-2), 133-147. DOI 10.1617/s11527-014-0481-6

12. Jin, F., \& Lees, J. M. (2019). Experimental Behavior of CFRP Strap-Strengthened RC Beams Subjected to Sustained Loads. Journal of Composites for Construction, 23(3), 04019012. https://doi.org/10.1061/(ASCE)CC.19435614.0000936

13. Lee, H. Y., Jung, W. T., \& Chung, W. (2017). Flexural strengthening of reinforced concrete beams with prestressed near surface mounted CFRP systems. Composite $\quad$ Structures, 163, $1-12$. https://doi.org/10.1016/j.compstruct.2016.12.044

14. Garcia, R., Pilakoutas, K., Hajirasouliha, I., Guadagnini, M., Kyriakides, N., \& Ciupala, M. A. (2017). Seismic retrofitting of RC buildings using CFRP and post-tensioned metal straps: shake table tests. Bulletin of Earthquake Engineering, 15(8), 3321-3347. http://dx.doi.org/10.1007/s10518-015-9800-8

15. Yang, S. H., Cao, S. Y., \& Gu, R. N. (2015). New technique for strengthening reinforced concrete beams with composite bonding steel plates. Steel and Composite Structures, 19(3), 735-757. https://doi.org/10.12989/scs.2015.19.3.735

Рукопис подано до редакції 18.03.2021

УДК 621.311 .1

І. О. СІНЧУК, С. М. БОЙКО, І. В. КАСАТКІНА, кандидати техн. наук, доценти, О. В. ДОЗОРЕНКО, асп., Криворізький національний університет

\section{АСПЕКТИ РОЗВИТКУ ВІТРОЕНЕРГЕТИКИ В УМОВАХ ЗАЛІЗОРУДНИХ ПІДПРИЕМСТВ}

Мета. Метою даної роботи є розробка тактики визначення вітрового потенціалу в умовах залізорудних підприємств 3 подальшим втіленням цього підходу до впровадження вітроенергетичних установок, як джерел автономного живлення в структурах систем електропостачання цих видів підприємств.

(с) Сінчук I. О., Бойко С. М., Касаткіна I. В., Дозоренко О. В., 2021 